\title{
AN INTEGRATED-SKILLS APPROACH TO LEARNING A FOREIGN LANGUAGE THROUGH THE USE OF THE PROJECT METHOD
}

\author{
A. L. Kotkovets \\ Kyiv, National Technical University of Ukraine \\ "Kyiv Polytechnic Institute" \\ a_kotkovets@ukr.net
}

The article deals with the peculiarities of an integrated-skills approach to learning a foreign language through the use of the project method. It studies characteristic features of communicative language teaching and the integrated-skills approach, that are aimed at students' acquisition of communicative competency applying their speaking, listening, reading, and writing skills in the process of interaction in real-life situations. An integrated development of four main language skills is emphasized in contrast to acquiring discrete skills. Content-based (including theme-based, adjunct and sheltered) and task-based types of an integrated-skills instruction are observed. The notions of communicative language teaching, integration, and project-based learning are defined in the paper. Tasks, which promote integrating reading with other activities, are also suggested in the article, as well as main criteria for texts selection, regarding the authenticity, difficulty level, length, and content of the text. The characteristic features of project-based learning, the origin of the method, types of projects according to the classification by Ye. Polat and stages of conducting project work are presented. Also highlighted are the advantages of the project method in foreign language teaching and the way students' language skills are integrated in the process of projects realization.

Key words: communicative language teaching, an integrated-skills approach, the project method, language skills.

Introduction. The constant search of new and effective methods of foreign language teaching in higher educational institutions in Ukraine leads to the use of modern techniques widely applied in European countries. The communicative approach and the integrated-skills method based on it are gaining popularity in our country and abroad. Project-based learning greatly fosters the development of language skills in an integrated manner, similarly to the way they are used in real communication.

Scientific and educational literature analysis suggests that the principles of integrated teaching have been investigated by numerous scientists. Language skills integration was studied by R. Oxford, E. Hinkel, T. Lyutaya and others. Issues related to the application of the project method in the teaching process can be found in the works of L. Miedviedieva, Ye. Polat, I. Fragoulis and others. However, the development of integrated language skills through the project-based learning is paid little attention, if any.

The aim of the article is to analyze the use of an integrated-skills approach in teaching a foreign language, paying special attention to the integration of reading with other activities; study the peculiarities and the advantages of the project method as well as its role in the students' integrated language skills formation and development. 
Integrated-skills approach. The principles of integration (integration of different disciplines, technology integration, skills integration etc.) have been widely used in education as the main purpose of higher educational establishments is to facilitate forming a well-developed person and a highly skilled specialist. Integration can be defined as an act or instance of incorporating or combining into a whole [4]. In foreign language teaching an integrated approach, which deals with the development of main language skills interdependently, is typically considered to be an outgrowth of communicative method. Communicative language teaching is defined as an approach to the teaching of languages that emphasizes interaction and is based on the idea that the goal of learning a language is to gain communicative competency [7, p. 66]. According to this method, real-life situations are modeled during the lesson and students acquire four main skills (speaking, listening, reading and writing) in the process of communication and interaction. The employment of the method makes studying process interesting and motivating unlike traditional approaches based on unreflective memorizing of rules and lexical items. Students work with language material for communicative tasks solving aimed at achieving purposes and intentions of communication [8, p. 39]. Some of the distinctive features of communicative language learning are the following: effective communication and comprehensible pronunciation are sought; communicative competence is the desired goal (i.e. the ability to use the linguistic system effectively and appropriately); intrinsic motivation will spring from an interest in what is being communicated [7, p. 67-68]. An integrated-skills approach also implies language acquisition in the process of communication. Students practise their speaking, listening, reading and writing skills while interacting with each other, like in the every-day life. The use of the method seems quite logical as language skills are not isolated in reality. Consequently, segregated-skills language instruction may appear unnatural and inefficient. Thus, the choice of classroom activities is of vital importance as it should be aimed at the development of four language skills in conjunction.

Types of integrated-skills instruction. Different tasks can be offered to students depending on the type of integrated-skills teaching method. At present, the models for integrated teaching with a communicative focus include an extensive array of curricula and types of instructional models, such as content-based, task-based, text based (also called genre based), discourse based, project based, problem based, literature based, literacy based, community based, competency based, or standards based and the list can be continued [3, p. 113]. Two main types commonly described are content-based language instruction and task-based instruction [6]. In content-based instruction, all the language skills are practiced in a highly integrated, communicative manner in the process of studying some content such as science, or physics. This method can be applied at any level of proficiency, but the topic will vary by proficiency level. Content-based instruction in its turn falls into three models which are known as

- theme-based (students practice integrated skills focusing on one topic, e.g. Education, Travelling etc., which must be interesting for them);

- adjunct (characterized by the coordination of learning language and content); 
- sheltered (students acquire knowledge about some subject in language they learn in a simplified manner to suit their proficiency level) [6].

Exercises offered to students might involve the discussion of the topic and preparation of projects.

Task-based learning engages students in interaction while participating in communicative tasks. The classroom activities might include problem-solving, exchanging personal information and other tasks which require understanding, reflecting and interacting in real-life situations.

The abovementioned activities can be beneficial for both students and a teacher, since the integrated-skills approach offers a series of advantages: it is highly motivating due to the fact that learners improve skills and acquire knowledge they will definitely use in their future life and career. Students learn to interact and communicate using these skills, while the teacher can see their progress in multiple skills and decide which aspect should be paid more attention. The method can be successfully applied for students of different ages and backgrounds.

Integrating reading with other activities. The main criterion for choosing activities for students is that they should be communicative and involve multiple, integrated skills. E. Hinkel points out that in order to make language learning as realistic as possible, integrated instruction has to address a range of language skills simultaneously, all of which are requisite in communication. Thus, teaching reading can be easily tied to instruction on writing and vocabulary, and oral skills readily lend themselves to teaching pronunciation, listening and cross-cultural pragmatics [3, p. 113]. For instance, listening to teacher's assignment to read the text in English, students employ their listening abilities. Then they might read the text and do exercises in pairs or small groups discussing the content and thereby using their reading and speaking skills. And finally learners can be asked to write summary or an essay to the related topic which helps develop writing skills. It should be noted that integrating reading with other activities can be an effective tool for integrated-skills learning. Reading offers the largest number of opportunities for language skills integration. Reading aloud, discussing the text, answering the questions and making up dialogues directly connect reading with listening and speaking. Writing summaries and performing exercises or speculating about the text in written form are examples of reading and writing integration.

In teaching English for specific purposes most lessons are commonly based on the texts related to students' future profession. Hence, special attention should be paid to choosing the reading material. Selecting texts for students a teacher should consider the following aspects:

- text authenticity (which provides connection to the world outside the classroom and shows how the real language is used);

- an appropriate difficulty level (which is determined by such factors, as presence of unfamiliar vocabulary, technical terms, syntactic structure of the text, complexity of ideas etc). Students' language proficiency level is to be taken into account. The text should not be too easy or too difficult, offering an appropriate level of challenge; otherwise students might be bored or intimidated. 
- manageable length;

- culture familiarity and content (the text must be interesting and profession-related, thus motivating students to read and learn).

In some cases allowing students to choose texts can be a good idea. It helps to personalize learning process and might contribute to students' autonomy and responsibility. Having chosen the right materials a teacher should consider text-based activities. Traditional reading comprehension exercises are multiple choice questions, true-false sentences, filling the gaps etc. However reading practice exercises can also be utilized to develop students' abilities to get the gist of the text (e.g. identify the main idea); to search for the logical links and cause-and-effect relationships (e.g. make up a plan to the text, find key words, give the headings to the paragraphs); to make comparison and contrasts; to voice their opinion and show attitude to the information in the text (e.g. evaluate the events or ideas in the text, give your own definition to the phenomenon, find more information to the topic and be ready to discuss it) etc. [10, p. 58]. The tasks listed above obviously not only enhance students' reading ability and fluency, but also facilitate the development of other language skills since the exercises can be done orally or in written form, individually or in pairs. Interesting and creative tasks can be motivating and thus become effective means of learning. The researchers recommend using comprehension strategies which help learners appreciate the text. These could be reflected in the following tasks: predict the plot of the text; comment on a passage or sentence; make a poster; put down questions and answers; speculate about information gaps; read/ write a review; write a letter; provide your own ending; give opinions about the text etc. [5, p. 30]. Not in all cases, however, can all of these activities be employed. Teaching English for specific purposes, for instance, is usually limited to the use of technical or profession-related literature which hardly boosts students' creativity. The project approach can compensate for the restrictions.

The use of the project method for integrated-skills development. The project approach has been used for a long time in education and is a widely recognized methodology today. Project Based Learning can be defined as a teaching method in which students gain knowledge and skills by working for an extended period of time to investigate and respond to a complex question, problem, or challenge [1]. It originated from supported by John Dewey experiential learning, or learning by doing, which implies that students obtain and reinforce their knowledge when they practically implement it. The advantages and main principles of projectbased learning were first described in detail by W. Kilpatrick. Nowadays, researchers highlight the following characteristic features of the approach:

a) promotion of manual activity instead of memorization and verbalism,

b) learners' active participation in the learning process, and

c) exploitation of facts relating to the immediate reality as a source for learning [2, p. 113]. The project method is being increasingly used in teaching a foreign language to learners of various ages and proficiency levels. The approach engages students in the organized cooperative work carried out independently which requires students to implement their knowledge for solving a problem or achieving an objective. Students work on a project, which is usually a long-term assignment, using the language they are learning. Projects can be of different topics, related to various 
knowledge fields and the results may be presented in diverse forms. A variety of project types was suggested by Ye. Polat, who classifies them according to:

- the main kind of activity (research, search, creative, role-played, applied etc.);

- the subject area (super-subject, inter-subject, mono-subject);

- the type of coordination (with direct coordination, with indirect coordination);

- the type of contacts (among the participants of one school, city, region or country);

- the number of participants (group, pair, individual)

- the duration [11, p. 43].

Despite the fact that projects can vary in complexity, subject and scope, any project work is conducted in several stages. Each of them engages students in communication and interaction and therefore promotes language skills integration. L. Miedviedieva describes four main stages of project implementation [9, p. 133]. The first stage is the preparatory one. It includes choice of the topic, putting students in sub-groups, assigning responsibilities, giving instructions to students and determining deadlines as well as assessment criteria. This stage requires the use of listening and speaking skills. If the project is text-based or book-based, students are to choose an author or a book during this phase. However, searching for literature, collecting information, processing and arranging it takes place during the second stage - the stage of conducting the project activities and performing tasks aimed at language skills development. The role of teacher here is to consult and guide as well as make sure the learners are exposed to the authentic materials and are able to make use of them. At this stage members of each group conduct research and discuss all issues related to the project. Reading, writing, listening and speaking are highly integrated at this stage which also prepares students to the next phase. It is during the third stage that students present the results of their work. The presentation phase helps students to reveal their creative potential and introduce the project (e.g. the one based on the text) in the form of Power Point Presentation; poster, drawn or created with the help of computer (picture, scheme, chart, table); presentation of the performance, dialogue modeling real-life situation; video etc. The last stage is the concluding one, at which the project results are discussed, analyzed and evaluated. As I. Fragoulis fairly points out, "evaluation refers to the assessment of the activities from participants and discussion about whether the initial aims and goals have been achieved, implementation of the process, and final products. Evaluation also entails assessment of the experience at individual and group level, identification of errors and problems, but also appraisal of the rich cognitive and experiential material gathered. Evaluation includes evaluation from others, as well as self-evaluation" [2, p. 115]. In the course of conducting project work students undoubtedly use their integrated language skills.

Project-based learning keeps its leading position among other methods of language teaching due to the considerable advantages it offers. The main of them are as follows:

- the method enhances the development of reading, writing, speaking and listening skills in an integrated manner; 
- it teaches students to work with authentic and up-to-date materials and to search them in various sources;

- being an interesting and motivating way of gaining knowledge, it raises the efficiency of the whole studying process;

- it gives students a possibility to apply their knowledge from other subject areas, therefore practicing and reinforcing the skills acquired during the lessons of different disciplines;

- the approach teaches the students to collaborate, improves interpersonal relationships in the group and helps to eliminate the barriers between students and a teacher and thus creates a positive classroom atmosphere. It also facilitates the development of the communication skills, such as teamwork, ethics and social responsibility, self-direction, oral and written communication, leadership, critical thinking, problem solving etc.;

- it encourages students to be self-disciplined and autonomous;

- it helps stimulate students' creativity and imagination.

The mentioned advantages clearly demonstrate an essential role of the method in foreign language instruction. Applying the project approach, every teacher will find it beneficial and add new advantages to the list. Though the organization and conducting of the project work might be time-consuming and seem difficult first, it will definitely bring positive results.

Conclusions. Much attention nowadays is being paid to the implementation of the innovative and the acknowledged methods in foreign language teaching. An integrated-skills approach implies language acquisition in the process of meaningful communication with the use of four main language skills simultaneously. Students practise their speaking, listening, reading and writing skills while interacting with each other in the real-life situations simulated in the classroom. Reading activities offer wide opportunities for integrated skills development. Various text-based tasks done in written or oral form require the application of speaking, listening, reading and writing skills. Project method used in the context of integrated-skills approach is considered to be an effective tool in language learning and teaching. It offers a range of remarkable advantages, such as the possibility for students to work collaboratively with authentic materials, applying theoretical knowledge in practice and enhancing integrated speaking, listening, reading and writing skills in the process of project preparation and presentation. The use of up-to-date information technologies for the project method implementation and integrated-skills development could be covered in future studies.

\section{ЛIТЕРАТУРА}

1. Coffey H. Project-based learning / Heather Coffey [Electronic resource]. - Access mode: http://www.learnnc.org/lp/pages/4753

2. Fragoulis I. Project-Based Learning in the Teaching of English as a Foreign Language in Greek Primary Schools: From Theory to Practice / Iosif Fragoulis // English Language Teaching Journal. - 2009. - Vol. 2, No.3. - P. 113-119. 
3. Hinkel E. Current perspectives on teaching the four skills / Eli Hinkel // TESOL Quarterly. - 2006. - № 40 (1). - P. 109-131.

4. Integration [Electronic resource]: The free dictionary. Access mode: http://www.thefreedictionary.com/integration

5. Lyutaya T. Reading Logs: Integrating Extensive Reading with Writing Tasks / Tatiana Lyutaya [Electronic resource]: English Teaching Forum 2011, Volume 49, Number 1. - Access mode:

http://americanenglish.state.gov/files/ae/resource_files/49_1_5_lyutaya.pdf

6. Oxford R. Integrated Skills in the ESL/EFL Classroom / Rebecca Oxford // ERIC Digest [Electronic resource]. - Access mode: http://www.ericdigests.org/2002-2/esl.htm

7. Richards J. C. Approaches and methods in language teaching / J. C. Richards, T. S. Rodgers. - Cambridge: Cambridge University Press, 2001. $270 \mathrm{p}$.

8. Методика викладання іноземних мов у середніх навчальних закладах: Підручник. Вид. 2-е, випр. і перероб. /Кол. авторів під керівн. С.Ю.Ніколаєвої. - К.: Ленвіт, 2002. - 328 с.

9. Мєдвєдєва Л.І. Проектна методика вивчення іноземної мови в контексті сучасних педагогічних технологій / Л.І. Мєдвєдєва // Наукові записки Тернопільського національного педагогічного університету імені Володимра Гнатюка. Серія Педагогіка. - Тернопіль, 2011. - № 4. - С. 129-134.

10. Пасічник С. Інтегрування читання у процесі вивчення іноземної мови / Сусанна Пасічник, Петро Черник // Studia Methodologica: [науковий збірник]. - Тернопіль: ТНПУ, 2011. - Вип. 33. - С. 55-59.

11. Полат Е.С. Метод проектов / Е.С. Полат // Метод проектов. Серия «Современные технологии университетского образования». - Мн.: РИВШ БГУ, 2003. - Выпуск 2. - С. 39-47.

\section{REFERENCES}

1. Coffey, H. (2008). Project-based learning. UNC School of Education. Retrieved from: http://www.learnnc.org/lp/pages/4753

2. Fragoulis, I. (2009). Project-Based Learning in the Teaching of English as A Foreign Language in Greek Primary Schools: From Theory to Practice. English Language Teaching Journal, $2(3), 113-119$.

3. Hinkel, E. (2006). Current perspectives on teaching the four skills. TESOL Quarterly, 40 (1), 109-131.

4. Integration. The free dictionary. Retrieved from: http://www.thefreedictionary.com/integration

5. Lyutaya, T. (2011). Reading Logs: Integrating Extensive Reading with Writing Tasks. English Teaching Forum, 49(1). Retrieved from:

http://americanenglish.state.gov/files/ae/resource_files/49_1_5_lyutaya.pdf

6. Oxford, R. (2001) Integrated Skills in the ESL/EFL Classroom. ERIC Digest. Retrieved from: http://www.ericdigests.org/2002-2/esl.htm

7. Richards, J. C. \& Rodgers, T. S. (2001). Approaches and methods in language teaching. Cambridge, UK: Cambridge University Press

8. Nikolayeva, S. Yu. (Ed.) (2002) Methods of teaching foreign languages in schools. Kyiv, Ukraine: Lenvit [in Ukrainian].

9. Miedviedieva, L.I. (2011). Project method of foreign language learning in the context of modern pedagogical technologies. Naukovi zapysky Ternopilskoho natsionalnoho 
pedahohichnoho universytetu imeni Volodymra Hnatiuka. Seriia Pedahohika, 4, 129-134 [in Ukrainian].

10. Pasichnyk, S.\& Chernyk, P. (2011). Integrating reading in the process of language learning. Studia Methodologica, 33, 55-59 [in Ukrainian].

11. Polat, Ye.S. (2003) Project method. Metod proektov. Serija «Sovremennye tehnologii universitetskogo obrazovanija», 2, 39-47 [in Russian].

\section{А. Л. Котковець. Інтегрований підхід до вивчення іноземної мови шляхом використання методу проектів.}

У статті розглядаються особливості інтегрованого підходу до вивчення іноземної мови шляхом використання методу проектів. Вивчаються характерні ознаки комунікативного та інтегрованого підходу, відповідно до яких, метою вивчення мови $\epsilon$ формування у студентів комунікативної компетентності шляхом застосування інтегрованих навичок говоріння, аудіювання, читання та письма у процесі взаємодії у змодельованих життєвих ситуаціях. У роботі визначено поняття комунікативного підходу до вивчення мови, інтеграції та проектного навчання. Представлено огляд завдань, що сприяють інтеграції читання 3 іншими видами мовленнєвої діяльності, а також основних критеріїв відбору текстів для читання. Досліджуються характерні риси проектного навчання, походження методу проектів та класифікація проектів, запропонована Є.С. Полат. У статті також висвітлені переваги проектної методики для розвитку інтегрованих мовленнєвих вмінь студентів у процесі вивчення іноземної мови.

Ключові слова: комунікативний метод, інтегрований підхід до вивчення мови, проектне навчання, мовленнєві навички

\section{А. Л. Котковец. Интегрированный подход к изучению иностранного языка при помощи метода проектов.}

В статье рассматриваются особенности интегрированного подхода к изучению иностранного языка путем использования метода проектов. Изучаются характерные признаки коммуникативного и интегрированного подхода, в соответствии с которыми, целью изучения языка является формирование у студентов коммуникативной компетентности путем применения интегрированных навыков говорения, аудирования, чтения и письма в процессе взаимодействия в смоделированных жизненных ситуациях. В работе определено понятие коммуникативного подхода к изучению языка, интеграции и проектного обучения. Представлен обзор заданий, способствующих интеграции чтения с другими видами речевой деятельности, а также основных критериев отбора текстов для чтения. Исследуются характерные черты проектного обучения, происхождение метода проектов и классификация проектов, предложенная Е.С. Полат. В статье также освещены преимущества проектной методики для развития интегрированных речевых умений студентов в процессе изучения иностранного языка.

Ключевые слова: коммуникативный метод, интегрированный подход к изучению языка, проектное обучение, речевые навыки 